\title{
Communicative Restrictions in Chinese Academic Discourse
}

\author{
Natalia G. Burmakina, Iuliia I. Detinko \\ Irina G. Nagibina and lana V. Popova* \\ Siberian Federal University \\ Krasnoyarsk, Russian Federation
}

Received 22.01.2020, received in revised form 01.02.2020, accepted 04.03.2020

\begin{abstract}
The article is devoted to the study of communicative restrictions (taboo) in the academic space of the People's Republic of China. Taboo in Chinese linguistic culture is based on the dominant principle of Chinese ideology - the principle of "saving of face" (face-saving), which allows people to effectively build harmonious relations in the academic community. The aim of the study is to identify the specifics of communicative restrictions in formal and informal academic communication within the framework of asymmetric, unequal, relations ("teacher - student", "research supervisor - student") and symmetrical, equal, relations ("teacher - teacher", "student - student"). With the help of ethnographic, descriptive, and contextual analysis methods, the authors identify and present seven most relevant topics of taboo functioning in the process of formal and informal academic interaction. The results of the study can be used in theoretical and practical courses on communicative linguistics, discursive linguistics and discourse analysis, pragmalinguistics and intercultural communication. In addition, the work may be useful in developing cross-cultural trainings in the framework of interaction with China on academic mobility programs.
\end{abstract}

Keywords: Chinese academic discourse, communicative restrictions (taboo), principle of "saving of face" (face-saving), taboo topics.

Research area: linguistics.

Citation: Burmakina, N.G., Detinko, Iu.I., Nagibina, I.G., Popova, I.V. (2020). Communicative restrictions in Chinese academic discourse. J. Sib. Fed. Univ. Humanit. Soc. Sci., 13(3), 304-315. DOI: $10.17516 / 1997-1370-0558$.

\footnotetext{
(C) Siberian Federal University. All rights reserved

* Corresponding author E-mail address: nburmakina@mail.ru, irina_nagibina@mail.ru, yanapopov@yandex.ru ORCID: 0000-0003-2102-4258 (Burmakina); 0000-0001-8254-8085 (Detinko); 0000-0001-9435-8617 (Popova) 


\section{Introduction}

The discursive construction of harmony is one of the dominant features of Chinese communicative style. Maintaining social harmony in the society is a part of language policy in the People's Republic of China (Wang, Juffermanx, Du, 2015: 300). Communicative restrictions and refusal to explicate certain meanings represent a discursive practice of establishing and maintaining harmonious relations in the society.

Over the past few decades, Chinese society has undergone significant changes in building relations between people, due to greater openness of culture and more frequent contacts with Western ideologies. Many topics that were considered closed in previous years are now openly discussed and they even become the subject of scientific research, for example, the intimate relationship of the youth (Blair, Scott, 2019). However, in the areas where there is a need to "declare a standpoint at issue unallowed or indisputable", Chinese culture still uses "strategic maneuvering", which allows using various techniques to evade a direct answer without breaking the taboo (Wu, 2019: 489, 490). The main idea of effective building of harmonious relations in Chinese linguistic culture is the principle of "saving of face". This article focuses on the specifics of academic interaction and taboo topics, based on this principle, which exist in Chinese academic discourse.

\section{Theoretical framework}

\section{and statement of the problem}

In almost every culture, there are situations where explication of the verbal and semantic content of a statement is undesirable, unacceptable, forbidden for those who communicate. This causes the appearance of communicative restrictions (taboos) in the discourse. Most researchers equate taboos with prohibitions, what is forbidden and what should be avoided, believing that observance of taboos is mandatory for all members of the society, and their violation leads to public censure.

Taboo has been studied in the works by Russian and foreign researchers, such as Zh.Zh. Varbot (Varbot, 1979), A.M. Katsev
(Katsev, 1988), V.B. Kashkin and E.M. Smolentseva (Kashkin, Smolentseva, 2005), M.L. Kovshova (Kovshova, 2007), I.S. Kon (Kon, 2016), K. Malgozhata (Malgozhata, 2003), E.A. Melikova (Melikova, 2005), N.B. Mechkovskaia (Mechkovskaia, 1998), O.A. Ruter (Ruter, 2007), I. A. Sadykova (Sadykova, 2003), J.G. Frazer (Frazer, 1983), L.V. Tsurikova and L.I. Grishaeva (Tsurikova, Grishaeva, 2005), C. Balle (Balle, 1990), R. Dahrendorf (Dahrendorf, 1961), S. Ganguin and U. Sander (Ganguin, Sander, 2006), R. Keller (Keller, 1987), A. Musolff (Musolff, 1987), R. Rada (Rada, 2001), H. Schröder (Schröder, 2003), M. Lin and P. Zhou (Lin, Zhou, 2014) and others.

A number of scholars distinguish between the concepts of taboo and prohibition, explaining the difference by internal motivation, attachment to moral and ethical considerations of the first and external motivation of the latter, (cf.: Schröder, 1995: 19; Musolff, 1987: 17). In other words, a taboo is not a prohibition from outside, it is an internal need to avoid something for some reason (Keller, 1987).

In linguistic literature, taboos are considered within the framework of the existence of forbidden and undesirable for discussion topics in some culture (Gazizov, 2011) or in the aspect of changes in tabooing norms in relation to different types of culture and different types of discourse (Tul'nova, 2010).

Although the semantic core of the concept of taboo in different interpretations contains approximately the same meanings (restriction or complete prohibition), there is no single understanding of this term. At the same time, researchers note the bright cultural specificity of the taboo, which determines the taboo topics, the degree of tabooing, the choice of language, communication tools to express the corresponding meanings; and emphasize the extreme complexity and topicality, as well as the internal inconsistency and versatility of this phenomenon. From the point of view of functioning, taboo is a cultural, social, and linguistic phenomenon; from the point of view of origin and motivation, it is a psychological phenomenon always limited by time and space. "The modern taboo includes its own process- 
ing as a moment of its existence. In this case, in the modern era, we can talk not about the disappearance of taboos in the act of processing, but about the constant updating of taboos in this very process ... Taboo does not disappear, but constantly works changing its semantic features" (Tsurikova, Grishaeva, 2005: 287). These conclusions explain the need to study the phenomenon of taboos in different areas of communication.

In this work, taboo is considered as a communicative phenomenon, which reflects the need to avoid certain expressions and topics, language nominations and non-verbal signs in a particular discursive situation, due to the pragmatic motivation of the communicator, taking into account the generally accepted language and conventional prohibitions, norms, traditions, values in the communicator's linguistic and cultural community and regulations (Popova, Kulikova, 2019).

Such a necessity for the representatives of Chinese linguistic culture is the principle of "saving of face" which is the essence of Chinese discourse and defines social and normative behavior of any person. As T.V. Ivchenko notes, face in Chinese culture is something obvious and tangible, but at the same time elusive and omnipresent (Ivchenko, 2014).

Face constitutes the Chinese daily social interaction and discourse and is perceived by the representatives of the Chinese culture a priori (Wang, Zheng, 2013). In the Chinese language "face" is represented by the signs 脸, 面子, 脸面, 表面, 情面, 形象, 印象, 外表. Their unifying semantic core is "social status", "conformity of a person to the norms of social behavior", "external side reflecting this conformity":

有面子 / have the honour; save/gain face;

爱面子 / be sensitive about one's reputation; be keen on face-saving; be concerned about one's face-saving;

给脸 / face-saving offer; be nice/considerate to others;

死要面子或受罪 / try to save one's face despite great cost to oneself;

失面 / lose face; be humiliated;

给面子 / show deference or praise publicly; show due respect for sb.'s feelings;
死不要脸 / be dead to shame; be devoid of shame; extremely shameless; lose all sense of shame;

真丢脸 / lose face; be disgraced; bring shame (disgrace) on oneself;

丢人 / lose face; be disgraced;

不留情面 / be very strict; disregard other's face or feelings;

厚脸皮和撕破脸 / brazen; shameless; impudent; cheek; thick-skinned;

人要脸, 树要皮 / face is as important to man as the bark is to the tree;

不看僧面看佛面 / not for the monk's sake, but for the Buddha's - (do sth. for a person) out of deference to sb. else; do sth. out of consideration for sb. else;

打肿脸充胖子 / slap one's face until it's swollen in an effort to look imposing; do sth. beyond one's means in order to be impressive; puff oneself up at (to) one's own cost; try to satisfy one's vanity when one cannot really afford to do so;

面孔 / face; prestige;

笑面虎 / a man with a big smile and evil intentions; smiling tiger - an outwardly kind but inwardly cruel person; a wicked person with a hypocritical smile; be a wolf at heart but innocent in appearance;

面目 / appearance; face; features; self-respect;

体面 / face; dignity; honourable; respectable;

面皮 / feelings; sensitivity;

颜面 / prestige; face;

面貌 / face; features;

装门面 / put up a front; maintain an outward show; keep up appearances;

青面獠牙和八面威风 / a long-toothed man with a livid face; one's face was blue and one's teeth stuck far out; terrifying in appearance; with a green face and ferocious fangs; with a green face and jagged teeth like a saw; (devils) with hideous blue-black faces, showing their teeth.

The concept of "face" goes back to the ethical and political tradition of Confucianism and is perceived by the native speakers of the Chinese language and culture as a dogma, an immutable rule of behavior in general, and an accurately formulated rules of communicative behavior in particular. 
Emphasizing the importance of the concept of "face" in Chinese communication, A.H. Smith compared this principle with the "golden key", which will open the secret doors of the Chinese behavior (Smith, 1894). The Chinese concept of "face" is translated into English by the lexical unit "face", in the Russian version we use the nomination "litso" (face). In non-Chinese versions, "face" is literally a reputation, a name, i.e. public opinion about the merits or demerits of someone. However, Chinese researchers agree that the signs 脸 and 面 have a broader meaning than their non-Chinese versions (Huang, 1991; Hou, Zhu, 2002; Guo, 2003; Gao, 2005; Wang, Zheng, 2013).

Chinese writer $\mathrm{X}$. Lu points out that the loss of face is behavior that breaks the framework of accepted regulation of human's actions (Lu, 1973: 130). At the same time, the writer and philosopher Y. Lin in his work “The Chinese" (中国 人), which describes Chinese culture in correlation with European, considers the meaning of "face" for the Chinese. He identifies three "deities" that rule Chinese nation, namely: "face" (面子), “fate" (命运) and “virtue" (恩惠), the main of which he considers "face". According to Y. Lin, "one cannot wash it [face] and one should not treat it with neglect, it is abstract and elusive" (Lin, 1994: 199). Face is a "cultural and communicative phenomenon of Chinese discourse that requires special attention and courtesy" (Nagibina, 2017: 108).

Thus, the emergence of communicative restrictions in Chinese linguistic culture is determined, as a rule, by the desire of its speakers to save face. The need to adhere to this principle in the process of interpersonal interaction is due to the ideas about values, about the conformity of a member of the society to the norms of behavior in this society, social status and the distribution of roles in different communicative contexts, in particular in academic discourse.

In this study, the authors understand the term "academic discourse" after L.V. Kulikova as "a normatively organized speech interaction with both linguistic and extralinguistic plans, using a certain system of professionally oriented signs, taking into account the status characteristics of the main participants in communication (scientists as researchers and/or teachers, as well as students in the university education), interpreted as a culturally marked communication system" (Kulikova, 2009: 222). Academic discourse is considered as the whole set of communicative phenomena in the framework of interaction within scientific and pedagogical areas.

The development of linguistic interaction in all types of Chinese discourse, including academic discourse, is carried out in accordance with the dominant principle of "harmony"/中 和, which is achieved by observing "hierarchical solidarity". The beginning of this solidarity is enshrined in the classical Chinese expression 尊长 爱 幼 ("respect the elders, love the younger ones") (Nagibina, 2017: 131), the postulate of proper communication in Chinese family. Since for the Chinese, the educational institution is a kind of "family hearth" (大学 就像 个大家庭 一样), the principles of family speech interaction operate within its walls. In Chinese academic discourse, the concepts of "senior" and "junior" include not only age characteristics, but also gender and status relations. Chinese academic community is a strict projection of the social structure of China, functioning according to generally accepted restrictions of Confucian ethics and morality.

\section{Material and methods}

The research is based on the fragments of Chinese academic discourse in the situations of interaction in which the participants occupy different positions in the hierarchy of university communication. In particular, we analyzed official and unofficial professional communication among teachers, researchers and students in the educational and scientific academic communities.

In this study, we considered communication between students and teachers who are in asymmetrical, unequal, relations, where one partner has a higher, more important, primary position, and the other is subordinate, secondary, lower. In this light, we identified the following communication pairs: "teacher - student", "research supervisor - student". 
In terms of symmetrical relations, i.e. relations based on equality, we identified the following communication pairs: "teacher teacher", "student - student". It should be mentioned here that relations of the participants in both pairs are graded according to the degree of their intimacy: acquaintances (认识 的 人), people who know each other well enough (熟人), close friends (闺 蜜 or 死党).

Using the ethnographic method of internal and external observation, we collected the situations of natural communication in Chinese academic environment, representing the implementation of the taboo, as well as some cases of taboo breaking (a total of 230 discursive fragments were analyzed). To interpret the language and communicative behavior and to characterize the taboo topics, a descriptive method and a contextual analysis method were used.

\section{Results and discussion}

As a result of the study, we identified the main taboo topics of official and unofficial professional communication in educational and research institutions of the People's Republic of China, determined by the linguistic and conventional restrictions, norms, traditions, values and regulations generally accepted in Chinese culture.

\section{Direct explication}

\section{of one's own scientific opinion}

Communicative restrictions in Chinese official academic discourse are manifested in the ways of explicating one's own scientific ideas, innovative approaches and methodology that are not considered traditional for the university scientific school, go beyond its framework, and even more, contradict it.

This convention is tacit, but strictly enforced by all parties of communication. In the written and oral modes of academic discourse, even when expressing one's own conclusions, they invariably refer to specific "unshakable" authorities and authoritative works in each specific field:

- 根据XX所说, …… / According to the $\mathrm{XX}$ source, ...
- 按照马克思经济理论/说法的基石, …... - / According to Marx's economic theory/ doctrine, ...

- 在他的著作中曾说过: “引文”。所以我们 认为 ...... / In his book it was said: "quotation". So, we think....

In all discourse-forming genres of academic communication, Chinese scholars prefer to use quotes from literary works or from the works of great philosophers, rather than directly express their own opinions and conclusions.

The presented observation of restrictions in expressing one's own position in Chinese academic discourse is confirmed in the works of Chinese researcher R. Ping, who notes a tendency to duplicate previously created works and repeat the colleagues' scientific results (Ping, 2012: 153).

\section{Critical assessment of the academic achievements of those who participate in scientific and educational activities}

In academic discourse, when a student is criticized by a teacher because of his lack of respect for learning and poor results, as a rule, the teacher's speech is performed in the presence of other students. However, a Chinese teacher will first point out the achievements of a criticized person (if they are absent, he will emphasize the positive personal qualities), and then delicately assess the student's actions. Moreover, in terms of quantity, the first part of the statement will be much larger than the part containing the condemnation. According to many foreigners with experience of studying in Chinese universities, the Chinese teachers' speech evokes a greater sense of guilt and awkwardness compared to the teachers' speech in their own culture, which is focused on the explicitness of critical statements. Such speech, therefore, only harms face (损 脸面), damages the reputation, but does not completely destroy it, so that the person who is criticized can escape loss of face (丢脸 面).

\section{Love relationship}

This topic is normal for communication in the communication pairs "teacher - teacher", "student - student", who are in the status of close friends. Mentioning the topic of love 
relationship in other communication pairs contains a threat to face of the interlocutor. This technique is used in case of intentional creation of a face-threatening potential:

- 你有对象吗? / Do you have a partner?

一你有男/女朋友吗? / Do you have a boyfriend/girlfriend?

- 你和你对象怎么样了? / How are you and your boyfriend/girlfriend?

- 你对象把你照顾得很好啊。/Your boyfriend/girlfriend takes care of you very well.

- 脸色怎么差, 被你对象甩了? / You look so bad, did your boyfriend/girlfriend abandon you?

- 成绩怎么差, 光顾着谈恋爱了? / Your academic results are so bad, you are not interested in anything except your romantic relationship.

In unequal relations, there is usually no addressee's verbal reaction to such statements: the silence of the addressee in Chinese linguistic culture can be interpreted as a desire to save one's own face (爱 脸面, 要 脸面) and recognition of the speaker's authority.

In symmetrical relations, rhetoric of this kind is interpreted as a way to harm face of the interlocutor (损 脸面), while the addressee feels free to turn on the protective mechanism and to break the taboo on the topics that damage the addressee's reputation.

\section{Personal life of a teacher}

\section{in the WeChat mobile communication system}

It should be noted that this multifunctional program is positioned by the Chinese as a universal application "for all occasions", with more than 900 million audience. In China, almost every smartphone owner uses WeChat, since it is not only a classic messenger, but also the system, including a mobile wallet, a built-in browser, an online store, etc. Publishing information about personal life is an unspoken taboo for university teachers and staff. This fact is due to the mechanism of face-saving and the desire to avoid potential self-discreditation.

$\mathrm{X}$. Wang and other scholars point out that maintaining order in the virtual sphere is an urgent task for the Chinese state to construct and preserve language harmony in society (Wang, Juffermanx, Du, 2016: 309).

For these reasons, social media pages usually contain information related to professional activities, public holidays, cultural traditions as well as neutral interests and hobbies (Fig. 1).

\section{Financial situation and psychological situation in the student's family}

According to the Chinese conventional prohibitions, the problem of the unfavorable

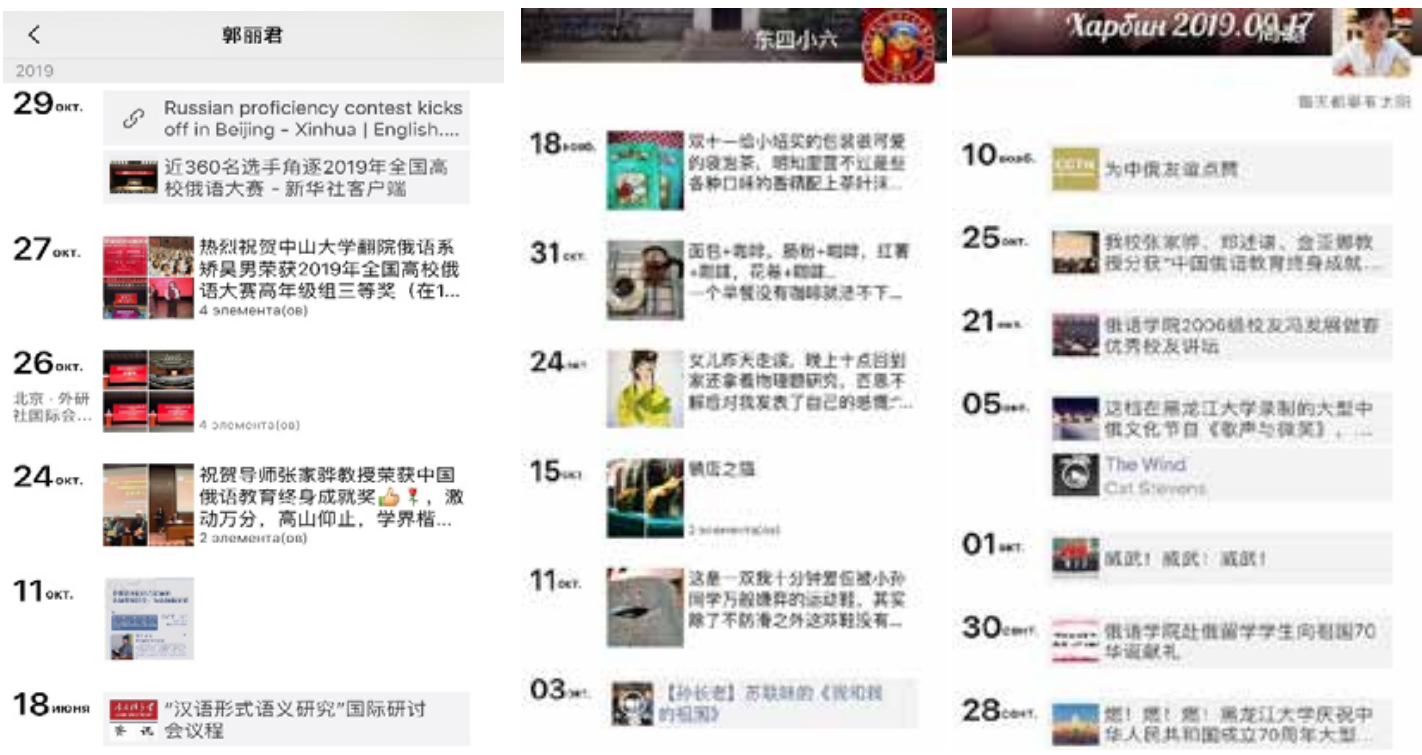

Fig. 1. WeChat profiles of the Chinese professors 
financial situation and psychological situation in the student's family is a topic that is not customary touched in communication within the pairs "teacher - student" and "student - student" being in the relations of acquaintances or people who know each other well enough.

In order to intentionally create a face-threatening potential, the participants of both communication pairs can violate the forbidden and stigmatized topic of financial support for the interlocutor:

- 家里这么穷, 还用这么好的衣服/手机/ 电脑？ 你好意思吗? 你哪来的钱? / Your family is so poor, but your clothes/cell phone/ computer is so good? Aren't you ashamed of yourself? Where did you get the money?

The topic of parents' divorce and incomplete family is undesirable and unacceptable in Chinese language culture. For this reason, its mentioning and discussion leads to the addressee's loss of face:

- 有娘生, 没娘养的。 / They gave birth to you, and there was no one to bring you up.

- 有人生, 没人教育。/ They gave birth to you, and there was no one to mentor you.

If the student's parents are divorced because of the use of domestic violence by one of the parties, then, in order to reduce the authority of the student himself, expressions that evoke negative associations in the communicant can be used:

- 你也有家暴倾向。 / You have a penchant for domestic violence too.

In the process of our observation, we also met the statements from the teacher as a way of collective pressure, addressed generally to the audience, without a specific nomination, while each of the participants in the communicative event understands to whom they are addressed and for whom they specifically represent a threat to the cultural and communicative self-sufficiency:

- 单亲家庭的孩子心里都不健全。 / The child's mental health in single parent families is bad.

Due to the fact that in such a communication pair the student is in the position of a subordinate, the only possible reaction of the implied addressee is silence, the absence of reverse verbal and nonverbal aggression.

\section{Expensive and prestigious acquisitions,} leisure time and gifts from the close people

The need to avoid this topic is primarily dictated by the Chinese social convention “wealth should not be visible" (财不露白), the archetype of which is an exhortation from the Chinese alphabet of the Ming dynasty, a collection of instructions for children: 客不离货， 财不露白。耾言不可听，听之祸殊 结。兄弟听之别，朋友听之疏，亲戚 听之绝。/ Your own things cannot be trusted to casual travelers; wealth cannot be demonstrated in order to avoid theft; you cannot listen to slander: slander between brothers leads to disagreement, slander between friends leads to alienation, slander between relatives leads to a breakdown.

In modern Chinese discourse, in addition to the desire to avoid an envious attitude to new expensive items, a person respecting a taboo is also guided by the desire to save face of an interlocutor who does not possess similar material values and acquisitions.

Nevertheless, in the unofficial academic discourse in the communication pairs "teacher - teacher" and "student - student" being in the relations of acquaintances or knowing each other well enough, the taboo on this topic is often broken. In the first situation, breaking taboo is carried out by the owner of material value:

- 我老公昨天买了一台大奔。 / My husband has bought a Mercedes.

- 是吗? 花了不少钱吧? 贷款几年啊?

/ Really? It must cost too much! How many years will you pay off the loan?

In the second situation, breaking taboo is carried out by the communicant who does not have an expensive acquisition, and the interlocutor either minimizes the money invested in the purchase or seeks to unleash a communicative conflict, verbally expressing aggression, indicating a high material wealth of the interlocutor:

- 听说你老公昨天买了一台大奔。 / They say that your husband has bought a Mercedes.

- 全款买的! / It is bought on credit.

- 袋款买的! 谁像你家啊! / It was bought on credit. We are not you to buy in cash! 


\section{Criticism of the university, its administration}

It is a culturally common taboo to express criticism of one's own university and its internal routine which is considered the strongest of all the conventional norms within Chinese academic community and, as a consequence, Chinese academic discourse. W.Y.W. Lo notes the strict hierarchy in Chinese scientific and educational space and the tendency to ignore the individual academic interests of its members (Lo, 2016: 35).

The university and its administration are perceived as their own family by all its research and teaching staff, students and technical staff (Cheung, Cheung, Hue, 2017). In this case, the university and its system have unshakable authority and authoritarianism (崇尚 权威), and their veneration, in turn, is one of the options for implementing the ancient principle of regulating ethical norms of social behavior, such as "devotion (service) to parents, norms (principle) of filial piety" (孝道).

The absence of criticisms and taboos on such communicative actions is also cemented by the Chinese nationalism as a unifying people ideology and preservation of the country's sovereignty through natural development, achievable through the strengthening of military and scientific potential.

One of the authors of this article being a lecturer at the Chinese university was a member of a group chat of Chinese teachers of Russian as a foreign language. Due to the fact that several colleagues from Russia were also teachers of linguistic disciplines, communication was carried out both in Russian and in Chinese, but according to strict standards of Chinese linguistic and cultural space. We witnessed the following message exchange in Russian, initiated by a Russian teacher:

- I don't understand why we are not participating in the competition organized by Guangdong University of Foreign Languages and Foreign Trade. We have always participated ... and stopped this year!

It should be noted that other teachers, including the head of the department, left this statement without reaction. Nevertheless, after two hours, the same Russian teacher again made an attempt to draw attention to his question and get a response from potential interlocutors:

- My Russian colleagues and their students from other universities in China are constantly organizing open events. Life is in full swing ... And we have some kind of calm life, nothing is being done.

In response, a Chinese colleague sent a single comment:

- This is the university's decision.

A day later, the head of the department, the moderator of the group chat, acting within the boundaries of his own cultural and discursive space as a continuum of the flow of social experience and national traditions, excluded the Russian teacher who broke the taboo and tried to criticize the university's actions as an authoritative institution from the group chat.

The attempts by this teacher to clarify the reasons for his exclusion during personal communication were simply ignored, that is, there was no verbal and non-verbal reaction from the recipients. The ultimate, resulting reaction to the communicative event, interpreted as "assault on face” (让 丢脸 面), was the refusal to renew the work contract with this Russian teacher. At the same time, the reasons for the refusal were also not verbalized, and the management arranged the registration procedure in such a way that the teacher was unable to comply with the deadlines for submitting the documents.

Another example of violation of the conventional norms of Chinese academic discourse, which had a large public scale, was found at one of the largest universities in China, the country's oldest university. It happened on the eve of the Mid-Autumn Festival connected with admiring the full moon, treating each other with "mooncakes" and burning the incense in honor of Chang-e, the mythical resident of the Moon. The "provocateurs" of the loss of face by the administration of the educational institution were its students who exchanged comments on the quality of the gingerbread donated by the university to each of the students. We consider it important to note that this holiday is traditionally celebrated by the whole family, and the semantics of the "circle of the 
family" is observed in sharing gingerbread cookies with everyone:

一学校送的月饼真难吃。 / The university mooncakes taste really bad.

- 学校送的月饼真硬。 / The university mooncakes are really stale.

- 学校送的月饼和诺基亚差不多了。

The university mooncakes are like Nokia.

These verbal evaluations were widely publicized in the Chinese media and attracted great public attention, which forced the university rector to make a public statement about the beginning of an internal check of the reasons for the unsatisfactory quality of confectionery products and to make a personal apology for what happened.

\section{Conclusion}

Thus, the functioning of communicative restrictions in the encoding and decoding information in Chinese academic discourse of official and unofficial formats is implemented by the principle of "saving of face" (脸面) as the main constituent of communication. Taboo topics in Chinese academic communication are the following:

1) direct explication of one's own scientific opinion;

2) critical assessment of the academic achievements of those who participate in scientific and educational activities;

3) love relationship;

4) personal life of a teacher in the WeChat mobile communication system;

5) financial situation and psychological situation in the student's family;

6) expensive and prestigious acquisitions, leisure time and gifts from the close people;

7) criticism of the university, its administration.

The functioning of communicative restrictions is determined by the distribution of communicative roles within a specific communicative situation. Taboo, the refusal to explicate certain meanings within the above-mentioned topics, contributes to the establishment and maintenance of harmonious relations in the context of academic discourse in China.

\section{References}

Balle, C. (1990). Taboos in the language [Tabus in der Sprache]. Frankfurt am Main, Peter Lang Verlag, $205 \mathrm{p}$.

Blair, S.L., Scott, C.L. (2019). "It Started with a Kiss": The Initiation of Sexual Intimacy Among Young Adults in China. In Sexuality \& Culture, 23, 1147-1166. DOI: 10.1007/s12119-019-09608-4

Cheung, Ch., Cheung, H.Y., \& Hue, M. (2017). Educational contributions to students' belongingness to the society, neighborhood, school and family. In International Journal of Adolescence and Youth, 22 (2), 226-237. DOI: $10.1080 / 02673843.2016 .1157827$

Dahrendorf, R. (1961). Politics in the garden of taboos [Politik im Garten der Tabus]. In Magnum. Zeitschrift für das moderne Leben. Köln, DuMont Verlag, 36, 58-73.

Frazer, Dzh.Dzh. (1983). Raznovidnosti tabu [Varieties of taboos]. In Zolotaia vetv' [The golden bough]. Moscow, 188-250.

Ganguin, S., Sander, U. (2006). Sensation, absurdness and taboos in the media [Sensation, Skurrilität und Tabus in den Medien]. Wiesbaden, VS Verlag für Sozialwissenschaften, $162 \mathrm{p}$.

Gao, J. (2005). Chinese psychology history. Beijing, Renmin Jiaoyu Press, 315 p.

Gazizov, R.A. (2011). Kommunikativnye tabu v nemetskoy lingvokul'ture [Communicative taboos in German linguistic culture]. In Vestnik Cheliabinskogo gosudarstvennogo universiteta. Filologiia i iskusstvovedenie [Bulletin of Chelyabinsk State University. Philology and Art History]. Cheliabinsk, 51, 8 (223), $37-40$.

Guo, B. (2003). A new stage in the development of modern psychology. Jinan, Shandong Jiaoyu Press, $220 \mathrm{p}$.

Hou, Y., Zhu, Y. (2002). The Impact of Culture on Chinese Thinking. In Bulletin of Psychology, 1, $106-111$.

Huang, X. (1991). Introduction to Psychology. Guangzhou, Beijing, Renmin Jiaoyu Press, 344 p. 
Ivchenko, T.V. (2014). Litso kitaitsa [Chinese face]. In Otechestvenye zapiski [National notes], 1 (58), available at: http://www.strana-oz.ru/2014/1/lico-kitayca

Kashkin, V.B., Smolentseva, E.M. (2005). Etnostereotipy i tabuirovannye temy v mezhkul'turnoi kommunikatsii [Ethnic stereotypes and taboo topics in intercultural communication]. In Kul'turnye tabu i $i k h$ vliianie na rezul'tat kommunikatsii [Cultural taboos and their influence on the result of communication]. Voronezh, Voronezh State University, 246-252.

Katsev, A.M. (1988). Iazykovoe tabu i evfemiia [Language taboo and euphemia]. Leningrad, A.I. Gertsen Leningrad State Pedagogical University, 80 p.

Keller, R. (1987). Word taboo and taboo words [Worttabu und Tabuwörter]. In Sprache und Literatur in Wissenschaft und Unterricht, 60, 2-9.

Kon, I.S. (2016). Kratkiy slovar' seksopatologicheskikh terminov [A brief dictionary of sexopathological terms]. In Natsional'naia psikhologicheskaia entsiklopediia [National Psychological Encyclopedia], available at: http://vocabulary.ru/dictionary/17

Kovshova, M.L. (2007). Semantika i pragmatika evfemizmov. Kratkiy tematicheskiy slovar' sovremennykh russkikh evfemizmov [Semantics and pragmatics of euphemisms. Brief thematic dictionary of modern Russian euphemisms]. Moscow, Gnozis, 320 p.

Kulikova, L.V. (2009). Kommunikativnyi stil'v mezhkul'turnom obshchenii: monografiia [Communicative style in cross-cultural communication: monograph]. Moscow, Flinta: Hauka, 288 p.

Lin, M. Zhou, P. (2014). How to avoid taboos in cross-cultural communication. Zhangzhou, Minnan Daxue, available at: https://max.book118.com/html/2018/0116/149046368.shtm

Lin, Y. (1994). The Chinese. Guangzhou, Beijing, Renmin Wenxue Press, 380 p.

Lo, W.Y.W. (2016). The concept of greater China in higher education: adoptions, dynamics and implications. In Comparative Education, 52 (1), 26-43. DOI: 10.1080/03050068.2015.1125613

Lu, X. (1973). Lu Xun. Collected Works. Guangzhou, Beijing, Renmin Wenxue Press, 460 p.

Malgozhata, K. (2003). Nevyrazimoe, nevyrazhaemoe i nevyrazhennoe dlya nositelia iazyka [Inexpressive, inexpressible and unexpressed for a native speaker], transl. by V.V. Dement'eva. In Priamaia $i$ nepriamaia kommunikatsiia: sb. nauch. statey [Direct and indirect communication: collection of research articles]. Saratov, 159-176.

Mechkovskaia, N.B. (1998). Iazyk i religiia. Lektsii po filologii i istorii religii [Language and religion. Lectures on Philology and History of Religions]. Moscow, FAIR, 352 p.

Melikova, E.A. (2005). Sovremennye proiavleniia evfemizatsii i tabuirovaniia [Modern manifestations of euphemization and taboo]. In Sbornik nauchnykh trudov Severo-Kavkazskogo gosudarstvennogo tekhnicheskogo universiteta. Seriia Gumanitarnye nauki [Collection of research works from North Caucasus State Technical University. Humanities]. Stavropol', 1, 159-160.

Musolff, A. (1987). Are taboos taboo? On the use of the word taboo in public usage [Sind Tabus tabu? Zur Verwendung des Wortes Tabu im öffentlichen Sprachgebrauch]. In Sprache und Literatur in Wissenschaft und Unterricht, 60, 10-18.

Nagibina, I.G. (2017). Formirovanie diskursivno-kommunicativnoi paradigmy v kitaiskom iazykoznanii: ot teorii k sotsial'noi praktike: dis...kand. filol. nauk [Formation of discursive-communicative paradigm in the Chinese linguistics: from theory to social practice: PhD thesis]. Krasnoyarsk, $232 \mathrm{p}$.

Ping, R. (2012). Systematic innovation, comprehensive development and going global: Some thoughts on the construction of an innovating system for philosophy and social sciences in China during the " $12^{\text {th }}$ five-year plan" period. In Social Sciences in China, 33 (3), 142-156. DOI: $10.1080 / 02529203.2012 .702948$

Popova, Ia.V., Kulikova, L.V. (2019). Tabuirovannye rechesmysly v diskursivnykh praktikakh institutsional'nogo obshcheniia: monografiia [Tabooed speech meanings in discursive practices of institutional communication: monograph]. Moscow, Gnozis, $264 \mathrm{p}$.

Rada, R. (2001). Taboos and euphemisms in contemporary German. With special attention to the properties of euphemisms [Tabus und Euphemismen in der deutschen Gegenwartssprache. Mit besonderer Berücksichtigung der Eigenschaften von Euphemismen]. Budapest, Verlag Akademiai Kiado, 213 p. 
Ruter, O.A. (2007). Tabu v fol'klornykh poemakh M. Tsvetaevoi (lingvisticheskii aspekt): dis. ... kand. filol. nauk [Taboo in the folklore poems of M. Tsvetaeva (linguistic aspect): PhD thesis]. Rostov on Don, $259 \mathrm{p}$.

Sadykova, I.A. (2003). Etnokul'turnye traditsii v rechevom povedenii lichnosti (na materiale etnorechevykh zapretov) [Ethnocultural traditions in the speech behavior of a person (based on the material of ethno-speech prohibitions)]. In Russkaia i sopostavitel'naia filologiia: vzgliad molodykh: sb. nauch. trudov [Russian and comparative philology: a view of the young: collection of research works]. Kazan', Kazan State University, 67-73.

Schröder, H. (1995). Taboo research as a task of intercultural German studies [Tabuforschung als Aufgabe interkultureller Germanistik]. In Jahrbuch Deutsch als Fremdsprache, 21, 15-35.

Schröder, H. (2003). Taboo [Tabu]. In Handbuch Interkulturelle Germanistik. Stuttgart, Metzler, 307315 .

Smith, A.H. (1894). Chinese characteristics, available at: https://archive.org/details/chinesecharacter00smitiala/page/n9/mode/2up

Tsurikova, L.V., Grishaeva, L.I. (2005). Kul'turnye tabu i ikh vliianie na rezul'tat kommunikatsii [Cultural taboos and their influence on the result of communication]. In Vestnik VGU. Seriia Gumanitarnye nauki [Bulletin of Voronezh State University. Humanities]. Voronezh, 2, 282-298.

Tul'nova, M.A. (2010). Tabu v kontekste globalizatsii [Taboo in the context of globalization]. In Politicheskaia lingvistika [Political linguistics]. Ekaterinburg, 4 (34), 176-81.

Varbot, Zh.Zh. (1979). Tabu [Taboo]. In Russkii iazyk: Entsiklopediia [Russian language: Encyclopedia]. Moscow, 345-346.

Wang, F., Zheng, H. (2013). Chinese cultural psychology. Guangzhou, Jinan University Press, 622 p.

Wang, X., Juffermanx, K., Du, C. (2016). Harmony as language policy in China: An Internet perspective. In Language Policy, 15, 299-321. DOI: 10.1007/s10993-015-9374-y

Wu, P. (2019). "I Have No Comment": Confrontational Maneuvering by Declaring a Standpoint Unallowed or Indisputable in Spokespersons' Argumentative Replies at the Regular Press Conferences of China's Ministry of Foreign Affair. In Argumentation, 33, 489-519. DOI: 10.1007/s10503-019-09504-z 


\title{
Коммуникативные ограничения
}

\section{в китайском академическом дискурсе}

\author{
Н.Г. Бурмакина, Ю.И. Детинко, \\ И.Г. Нагибина, Я.В. Попова \\ Сибирский федеральный университет \\ Российская Федерачия, Красноярск
}

\begin{abstract}
Аннотация. Статья посвящена функционированию коммуникативных ограничений (табу) в академическом пространстве Китайской Народной Республики. В основе табуирования в китайской лингвокультуре лежит главенствующий принцип китайской идеологии - принцип «сохранения лица», который позволяет эффективно выстраивать гармоничные отношения в китайском академическом сообществе. Целью исследования стало выявление специфики актуализации коммуникативных ограничений в формальном и неформальном академическом общении в рамках несимметричных, неравных отношений («преподаватель - студент», «научный руководитель - студент») и симметричных, равных отношений («преподаватель преподаватель», «студент - студент»). Для выполнения поставленных задач авторы использовали этнографический и описательный методы, а также метод контекстуального анализа. В результате исследования выделены семь наиболее актуальных тем функционирования табу в процессе формального и неформального взаимодействия субъектов академической коммуникации. Полученные результаты могут быть использованы в теоретических и практических курсах по коммуникативной лингвистике, дискурсивной лингвистике и дискурс-анализу, прагмалингвистике и межкультурной коммуникации. Кроме того, работа может быть полезной при разработке кросс-культурных тренингов в рамках взаимодействия с Китаем по программам академической мобильности.
\end{abstract}

Ключевые слова: китайский академический дискурс, коммуникативные ограничения (табу), принцип «сохранения лица», темы-табу.

Научная специальность: 10.02.00 - языкознание. 